\title{
Place Branding: What Distinctiveness for the Southern Territories? An Analysis Through the Prism of a Moroccan Region
}

\author{
Sanaa Moussalim \\ Moulay Ismail University
}

Over the past 20 years, place branding has received increased attention, both as a practice and as a subject of academic studies. Its rapid expansion in territories can be explained by globalization and its corollary, the feeling of fierce competition between places to attract investment and visitors on the one hand, and the adoption by the public sector of private methods and tools, as part of the managerialist trend, on the other hand. Based on the results of research conducted in the Oriental region of Morocco and a literature review, we propose a comparative study of place branding practices between two French regions and the Moroccan Oriental region, in order to define the similarities and differences, in an attempt to outline a marketing practice specific to Moroccan regions.

Keywords: place branding, place management, territorial development, l'oriental, Morocco

\section{INTRODUCTION}

Fundamental changes in economics, technology, demographics and politics are reshaping the environment of cities and regions on every continent. These changes are related to intense urbanization and increasing metropolization, the development of information and telecommunication technologies and the increased mobility of economic activities, people and resources (Van Den Berg \& Braun, 1999). This situation introduces a process by which territories feel they are in open competition with each other (Camagni, 2002; Kotler et al., 1993) to attract new investments, develop tourism, or become attractive poles for new businesses, in competition with the whole planet (Proulx \& Tremblay 2006). This competition is for "their global share of consumers, tourists, investors, students, entrepreneurs, international sporting and cultural events, and for the attention and respect of the international media, other governments and the populations of other countries" (Anholt, 2007, p.1; Kotler et al., 1993, p. 9).

In recent years, cities and regions have discovered that marketing can be a powerful instrument in this new management style (Van den Berg \& Braun 1999), to develop their attractiveness and competitiveness (Benko, 1999; Meyronin, 2009; Noisette \& Vallérugo, 2010). Thus, communication campaigns by local authorities, cities, and regions have become more widespread in recent years and rub shoulders with those of consumer brands on the web, in social networks and in the more traditional media (Meyronin, 2009), in almost all regions of the world, although much more so in the countries of the North than in those of the South.

This article therefore proposes to study the place branding practices of a Moroccan region, the Oriental, and to compare them with other experiences in two French regions (the Champagne-Ardenne region and the Nord-Pas-de-Calais region) to identify common points and especially to distinguish the possible 
specificities of the marketing of Moroccan regions. This research work was carried out in immersion, since we worked for a few years in the region, and for the Agence de l'Oriental, a public institution in charge of the development and promotion of the Oriental region.

\section{PLACE BRANDING, A NEW PRACTICE}

In recent years, "formal" place branding has received increased attention, both as a practice and as a subject of academic research, as cities and territories have used a lot of "informal" marketing for centuries (Kotler, 2009).

\section{An Attempt at Defining Place Branding}

Place branding is an approach that aims to develop the location offer, based on knowledge of the environment, geographic, demographic, cultural, economic, social and political (Chamard et al., 2013). It is generally associated with the marketing of territorial organizations, insofar as a territory can only develop through organizations (generally administrative institutions, regional councils for regions, development agencies, investment promotion agencies, chambers of commerce, regional investment centers, etc.). Place branding is not a simple institutional communication undertaken by territorial authorities.

It is in fact a set of assets and opportunities, aimed at an audience whose needs have been identified and understood. The resulting offer highlights how the territory meets these expectations in competition with other territories and regions, by presenting a unique selling proposition (USP) ${ }^{1}$.

However, Place branding has its own specificities because the territory is not a company. Indeed, while the company controls more or less well all its competitive advantages, territories control only a small part of them. The climate, the site, the history of a city are determining factors in its attractiveness and over which no player has the slightest control. But above all, while the primary function of a company is to produce and sell services or goods, the elected officials of a territory have a major responsibility to ensure that the citizens of that territory live in the best possible conditions. This is why some elected officials are sometimes reluctant to use private methods in public management. "Place branding is not the enemy of territories, as long as it supports real and measurable efforts in favor of economic, cultural, urban and social development... "(Meyronin, 2009). In other words, one must "be in the seduction, certainly, but also be in the construction of meaning, at the crossroads of a history, a geography, an ambition and an imaginary to be built for, and with those who live there, and for those whom one wants to bring there" (Meyronin, 2009). Place branding has a practical objective beyond image construction. When successful, this practice helps regions target specific end markets, reach circles of influence and shape public opinion.

If Place branding is, particularly in the USA where it originated, a multi-billion dollar industry where places are aggressively sold (Kotler et al., 1999; Ashworth \& Voogd, 1994; Ward, 1998; Rainisto, 2003), European experiences in this field are still recent, although there are cases of schools, particularly in large European cities, such as Lyon in France, Barcelona in Spain, or London in Great Britain. In the countries of the South, practices are very recent and date back to the last few years, with some very successful special cases such as Dubai. In Morocco, Casablanca has distinguished itself by the launch in 2016 of a marketing strategy and a territorial brand, WeCasablanca. Other cities, such as Marrakech, Agadir or Essaouira, have interesting practices. The regions have taken their turn, such as the Tangier-Tetouan-Al Hoceima or SoussMassa-Daraa region, the Oriental region being the only one to have put in place a thoughtful, integrated and formal strategy (Moussalim, 2017).

\section{Public Management and Marketing of Territories}

Traditional marketing, with its traditional tools, could not be applied as such to the territories. It was the emergence of service marketing in the 1980s and that of relational marketing, that helped play a key role in the affirmation of public marketing, adopted by public organizations, in an environment dominated by the philosophy of New Public Management (NPM), and that contributed to providing it with more relevant lines of thought and tools (Rochette \& Cassière, 2012). 
The NPM has been adopted by both public organizations and territories. Indeed, the increasingly farreaching decentralization reforms have transferred part of the State's decision-making power and competences to local structures, which manage institutional territories, which have become project territories, in a logic of partnership between different stakeholders (Hernandez, 2007). It is now widely accepted that territories are at the heart of economic development and that regional authorities are now major players in globalization. Thus, regions are faced with the same managerial challenges as companies or organizations. With decentralization, optimization of resources and increasingly high user expectations, regional public organizations have been led to initiate and drive change using NMP tools. This is known as territorial public management, which uses the same tools as private management, including marketing.

\section{Territorial Development and Marketing}

Marketing has now become a strategy widely deployed by local authorities, mainly at the level of cities and regions, to improve their governance (Eshuis, Braun \& Klijn, 2013). It is used to increase the competitiveness of territories and attract target groups such as tourists, new residents, businesses and investors (Bennett \& Savani, 2003; Braun, 2008), as well as to improve the living environment of residents. This effort can result in the creation and promotion of a positive image, but must above all develop the territorial product, i.e. the development of the territory itself. This development should not only take place in response to the demand of target groups, tourists, companies or investors (as is often argued in the literature, see among others: Greenberg, 2008; Kavaratzis, 2004, Kotler \& Gertner, 2002). Territorial development must first of all be thought of and done for the good of local populations and residents, with the targeting of investors and companies having as its primary objective the creation of wealth and jobs at the local level.

In the United States alone, \$20 billion was spent annually in the 1990s on economic development programs (Hocomb, 1994). In European countries, large, albeit smaller, budgets from European and national funding are spent within the same framework. Over time, the logic of economic development of territories has changed to be replaced by a marketing logic. Cities and territories are increasingly led to produce shared diagnoses of their socio-economic situation, to develop positioning, strategic plans and implement marketing plans. These experiences are numerous and plural today at the international level, while this practice is still in its infancy in Morocco.

In this article, we will focus on the case of the Moroccan Oriental region, having deployed a place branding strategy for over ten years. Then, a comparative approach is carried out with other conurbations in order to identify the differences and specificities inherent to the marketing of territories in Southern countries, the Oriental as an example.

\section{FIELD OF STUDY AND METHODOLOGY}

We are here at the level of the regional entity. The evolution of the territorial organization in Morocco, towards a model of "advanced regionalization" is at the origin of a renewed interest in the territory, which has become a living space with initiatives to better organize it and be able to live there better. The Region seems to represent "a privileged relay between the national and the global" (Ben Hachem El Harouni, 2008, p. 171), and is the ideal level between the State and the lowest level of territorial authorities, i.e. the commune, constituting the fundamental territorial and social unit of development. It provides a critical mass for development since it is large enough to be able to achieve a reasonably complex level of development and small enough to allow for the direct participation of the population in the decision-making process (Ben Hachem el Harrouni, 2008). The region is also the best territorial level at which to conduct place branding policies and strategies, since the commune has neither the human nor the financial resources to do so, while the prerogatives of the province do not allow it to do so (Moussalim, 2017).

The methodology followed is that of the case method (Yin, 2003). We chose the Oriental region as a unique case for our research. Our empirical research was carried out on the basis of a literature review ${ }^{2}$ and interviews $^{3}$ with leaders of public, private and associative organizations at the regional, national and international levels. The tools and instruments used allowed us to collect and analyze a corpus of data, using 
the Thematic Content Analysis (TCA) method with the help of NVIVO 4 software. The international location, apprehended thanks to a bibliographical study, and to the empirical study in the Oriental region, will concern two French regions which have very close relations with the Oriental region. The first is the Champagne Ardennes region, twinned with the Oriental since the 1990s, and sharing with it many common points relating to their situation as transit regions, the significant disparities between the territories but also to strategic economic sectors such as agriculture or agri-food, or logistics. Next, we will study the case of the Nord-Pas-de-Calais region, whose capital Lille has been twinned with the city of Oujda since 2005.

\section{PLACE BRANDING PRACTICES OF THE REGIONS STUDIED}

\section{Case of the Champagne-Ardenne Region in France}

The Champagne-Ardenne region (CA) is a former French territorial collectivity (from 1982 to 2015). In the last territorial division of 2015, it merged with Alsace and Lorraine to form the new Grand Est region. Having had privileged relations with the Moroccan Oriental for more than twenty years, we will focus on this region, within its former geographical boundaries. The CA was ranked 12th among French regions by its surface area ( $4.7 \%$ of the national metropolitan area). Due to its geographical position and the activities of its inhabitants, it has always been turned towards both the Paris Basin and the Great East of France. Four departments, the Ardennes, the Aube, the Marne and the Haute-Marne, and 1,945 municipalities, administratively structured this territory which stretched over $350 \mathrm{~km}$ from North to South.

The CA region had some good economic indicators: 1st region for cast iron production, 3rdmetallurgical region, 2nd food-processing region and $25 \%$ of French hosiery production. The major key sectors for the economic development of CA are ${ }^{5}$ : The food industry, the textile industry, metallurgy, the packaging industry, logistics and biomolecules/biomaterials. Located at the heart of the major trade flows between the North Sea, Flanders and Italy, the CA has always been a transit region, like the Oriental region, as we will see. It is well endowed with transport infrastructures, especially on the east-west axis, reinforced by the arrival of the TGV Est high-speed train in 2007.

These few advantageous rankings should not mask alarming indicators. Indeed, the region was also marked by great disparities between territories. In terms of social cohesion, it presents a very particular profile, linked on the one hand to the consequences of the serious industrial changes underway and on the other hand to its weak urban structure. Indeed, the weakening of the activity basins is reflected in the increase in the number of job seekers and recipients of minimum social benefits. To reverse this trend, in 2005, CADev (Champagne-Ardenne développement), the economic development agency for the Champagne-Ardenne region, was created. It is a private structure organized in the form of an association, financed mainly by the regional council, and chaired by a company director. Its main missions are to :

- Prospect in France and abroad for companies likely to set up in the Champagne-Ardenne region.

- Accompany strategic projects of regional companies,

- Promote the assets of the Champagne-Ardenne region.

The CADev is made up of a team of about fifteen people and relies on internal skills in business intelligence, project engineering (regulatory aspects, public aid, financial analysis, site location research, etc.) and marketing. When it was created, CADev benefited from a budget of $€ 1.5$ million, thanks to crossfinancing from the Region, the European Union, Datar, the Caisse des Dépôts et Consignation, and the Ardennes General Council, as well as "participation and membership fees" revenue.

In 2009, the various players in the region decided to deploy a "Champagne-Ardenne" brand strategy as part of a place branding approach, with the launch of an "invest in Champagne Ardenne" website in the summer of 2011. This site is only aimed at potential customers of the territory, companies and potential investors. Then the CADev launched its Internet portal dedicated to the Transport and Logistics sector: "Logistics in Champagne- Ardenne", one of the strategic economic sectors for the Region.

This marketing strategy for the Region is also accompanied by other strategies, led by the main cities in the region, including the city of Reims in particular. Thus, in 2003, at the initiative of the city of Reims, Reims Métropole and the Reims \& Epernay Chamber of Commerce and Industry (CCIRE), the Invest in 
Reims (RCD) agency was created, with a team of 7 people and a budget of $€ 1.3$ million, with the mission of promoting and developing the economic development of the metropolis of Reims.

In 7 years, Invest in Reims has supported the creation of more than 4,200 jobs by welcoming more than 95 companies, including many groups based in Paris. Since its creation, this agency has developed a triple strategy of differentiation, conquest and pride in the region based on "celebrity marketing" ${ }^{\prime \prime}$ and cobranding ${ }^{7}$ around a single brand: Invest in Reims.

\section{Nord-Pas-De-Calais Region in France}

The city of Lille is the capital of the Nord-Pas-de-Calais region (NPDC), which merged with the Picardie region, now called Hauts-de-France, as part of the 2015 territorial reform. Lille and Oujda have been united by a partnership agreement for more than fifteen years. The two cities wanted to contribute to the Euro-Mediterranean rapprochement by relying on their strong human ties (more than $50 \%$ of Lille's inhabitants of Moroccan origin come from the Oriental region) and therefore on their common issues, such as their border position. The numerous partnership projects range from the promotion of economic development to social and cultural development, through responsible tourism or the social and solidarity economy.

The Universities of Lille and Oujda have also developed numerous collaborations illustrated by a great diversity of joint research and articles, dual degree courses and the organization of scientific events.

The NPDC region underwent many changes during the 20th century. Fourth French region for its GDP, a privileged geographical situation in the heart of Europe, a capital (Lille) with a European status, historical economic sectors (railways, automobile, etc.): Nord-Pas-de-Calais had serious assets and knew a real diversification, industrial and tertiary, symbol of its economic renewal. However, this region was facing a serious industrial crisis, like the Oriental region, in the sense of a profound recomposition of the productive system. In thirty years, between 1975 and 1992, the region saw the disappearance or decline of several key sectors of its economy: the mining sector, the textile sector and the iron and steel industry.

The region had the image of a densely populated industrial region, however a significant part of the territory is devoted to agriculture. The automobile industry is a sector in reconversion. Formerly marginal, it has become a major player in the regional economy with the installation of a dozen modern plants for manufacturers such as Renault, PSA Peugeot Citroën and Fiat or more recently Toyota, and their subcontractors. Logistics is another important economic sector in the Region.

In 2000, the former CEO of the private group "3 Suisses International" created an association under the law of 1901, Créativallée, to promote and raise awareness of the spirit of entrepreneurship in the Nord-Pasde-Calais region. In June 2008, on the initiative of the same person and the vice-president of the regional council, the Créativallée association saw its mission broaden to be a pioneer in place branding and carry the new regional economic promotion brand, "Nord-Pas de Calais, La Créativallée". Its primary objective has been to position Nord-Pas de Calais as "the valley of creation" in Europe, in the image of Silicon Valley. With a team of seven people and an annual budget of $€ 750,000$, the Créativallée association, supported by the Regional Council, the ERDF, the Caisse des Dépôts et Consignations, the Conseil Général du Nord and all the regional players in business creation and innovation, has set up an ambitious place branding strategy, with the slogan "Nord-Pas de Calais, La Créativallée", which represents a brand and a shared approach to place branding. It federates and animates the economic and institutional actors of the region to contribute to the economic development of the region by working on its image, creativity and the quality of support for entrepreneurs.

This strategy is aimed at project leaders, whether regional or from another French or foreign region, who would like to do business in the region. Through its territorial offer, the Créativallée proposes structures adapted to the needs of investors, regular project monitoring, and support in a dense, coordinated and efficient network.

The place branding plan for the NPDC region is very diverse. In addition to the tools developed, the creativallée implements a very active web 2.0 strategy and has been animating since the launch of the brand a network of ambassadors with more than 1100 members, the international network of the $\mathrm{Ch}^{\prime} \mathrm{tis}^{8}$ of the world. 
In addition to the network of ambassadors, several vectors of communication are used to publicize the territory's approach:

- Viral marketing: buzz, teasing, word of mouth ...

- New modes of communication (especially web 2.0: Video, Facebook)

- Dissemination of the region's success stories through videos and written testimonials,

- $\quad$ Or the "Project Center, northern France the Lille Region".

This Project Center is a high-end multimedia room that uses digital animations to convince investors and specifiers of the region's competitive advantages. It is therefore a place branding tool which, by enhancing and illustrating information about the Nord Pas de Calais, contributes to the sale of the territory by the partners in charge of the international attractiveness of the region.

As in the case of the Champagne-Ardenne region, the NPDC region in doing its place branding does not feel competitive with its own cities. The Lille metropolis has its own agency for promotion, with an association status: the Agency for the International Promotion of Lille Metropole APIM which accompanies companies in their projects of establishment and development and is in charge of promoting the metropolis internationally.

Free of charge and in complete confidentiality, a team of project engineers, a one-stop shop for investors, helps them in their steps, whether it is the installation of a first representative office in Europe, an industrial unit, a research center, a head office, a logistics center or the development of new activities. APIM is financed and administered on an equal footing by Lille Métropole Communauté urbaine and the Greater Lille Chamber of Commerce and Industry, with which the Conseil Général du Nord is associated.

An analysis of the practices of the two French regions leads us to make the following observations:

- Both regions have chosen to implement place branding strategies to promote their regions relatively recently, in the 2000 s.

- These strategies are essentially oriented towards investment attractiveness, with free tools and instruments for support.

- Both regions have relied on the web, for its most recent versions (web 2.0) and on important networks of ambassadors to relay information on the potential of the two territories and the different investment opportunities present there.

- Both regions rely on small, dedicated teams, headed by private managers, and large budgets to promote their territories.

- Place branding interests different levels of institutions: national, regional, departmental, communities of communes, communal... All these territories, according to their means, act for the promotion of their territory. Thus, nothing prevents the main cities to do their marketing, next to their regions.

\section{Case of the Moroccan Eastern Region}

The Oriental region is one of the 12 regions of Morocco, the result of the last administrative division of 2015. The Oriental region, whose administrative boundaries have not changed since the 1972 division, was thus added a new province, that of Guercif. Located in northeastern Morocco, the region covers 90,130 $\mathrm{km}^{2}$, or $12.7 \%$ of the national territory.

The region, which has suffered from a great delay in development during the last decades, had continued to build its economy on sectors that had reached their final stage: mining, pastoral economy, border trade, etc. The region had continued to build its economy on sectors that had reached their final stage: mining, pastoral economy, border trade, etc. Today, the mines have been closed, the pastoral economy has suffered the effects of the recurrent drought of the last 30 years, while border trade has declined with the closure of the borders with Algeria and the dismantling of tariffs.

The region's economy is handicapped by many problems, including the dominance of tertiary sector activities (trade and services) with a large proliferation of unorganized activities. The proportion of the working population employed in this sector thus reached nearly $51 \%$ of the region's total employed labor force in $2009^{9}$. 
The region also suffers from many handicaps, including significant urbanization and a significant decline in the rural population, recurrent droughts that undermine agriculture, livestock and water stocks in the region, and a high unemployment rate that far exceeds the national average (17.9\% compared to $9.9 \%$ nationally ${ }^{10}$ ). This situation has persisted for many years despite the launch by the public authorities in 2003 of the Royal Initiative for the Development of the Oriental Region (IRDO), and the creation, in its wake, of the Oriental Development Agency.

\section{L'AGENCE DE L'ORIENTAL: A PLACE BRANDING INSTRUMENT}

Prior to 2003, the Oriental region suffered from a very negative image at the national level, if not an image deficit at the international level. Therefore, the Oriental Agency made a point of including in the list of its missions, that of implementing an appropriate communication strategy to promote the image and attractiveness of the Region. Since 2009, the Oriental Agency has deployed, with the help of a communication consulting agency, a multi-channel communication, targeting different targets: the diaspora of the Oriental in other regions of Morocco and abroad, investors, intellectuals, opinion leaders, and the national and international press. This place branding strategy of the Oriental region, thought, implemented and led by the Agence de l'Oriental, has three priority objectives: to improve the image of the region, increase its visibility, and enhance its attractiveness. To achieve these objectives, 5 priority areas of intervention have been identified ${ }^{11}$ :

1. Economic, social and cultural promotion at the local, national and international levels ${ }^{12}$;

2. Promotion of investment in the Region through support from the United Nations Conference on Trade and Development, UNCTAD ${ }^{13}$;

3. Publication and production of promotional documents for the region and communication tools, targeting both the local population and visitors to the Region ${ }^{14}$;

4. Implementation and development of a communication strategy that targets the local population, through the organization of proximity events ${ }^{15}$;

5. Marketing of the territory, through the web, thanks to the realization of a high- performance and modern Internet portal for the region ${ }^{16}$.

This marketing strategy for the Oriental region seems at first glance to be very complete and aimed at all potential customers of the territory. The detailed study of this strategy ${ }^{17}$ has shown all the interest of using place branding tools for the promotion of a region, a completely innovative approach and still in experimental stage in Morocco. Below, a table, drawn up by ourselves on the basis of our experience of working at the Oriental agency and a compilation of internal documents, presents in a succinct manner the objectives to be achieved by the region and the place branding (TM) tools used by the Oriental agency to achieve them.

TABLE 1

BRIEF PRESENTATION OF THE MARKETING TOOLS USED BY THE ORIENTAL REGION

\begin{tabular}{|l|r|}
\hline \multicolumn{1}{|c|}{ Objectives to be achieved } & \multicolumn{1}{c|}{ Place Branding Tools Used } \\
\hline $\begin{array}{l}\text { Economic promotion of the } \\
\text { territories }\end{array}$ & $-\begin{array}{l}\text { Support, organization and participation in economic promotion } \\
\text { events, including those organized by the diaspora in the region } \\
\text { (economic fairs, cultural weeks, organization of investment } \\
\text { seminars, ...) }\end{array}$ \\
\hline $\begin{array}{l}\text { Promotion and cultural and } \\
\text { sports activities in the territories }\end{array}$ & $-\begin{array}{l}\text { Creation and reinforcement of cultural (regional or municipal } \\
\text { libraries, cultural centers and museums) and sports } \\
\text { infrastructures. }\end{array}$ \\
$-\begin{array}{l}\text { Support to local, regional and international actors for the } \\
\text { organization of festivals (Rai festival, theater festival, cinema, } \\
\text { reading,...); }\end{array}$ \\
\hline
\end{tabular}

Journal of Applied Business and Economics Vol. 23(4) 2021 


\begin{tabular}{|c|c|}
\hline & $\begin{array}{l}\text { - Encouragement of artistic creation and visual arts (painting, } \\
\text { sculpture and photography) } \\
\text { - Participation in the financing of sports clubs in the region. }\end{array}$ \\
\hline $\begin{array}{l}\text { Research and knowledge } \\
\text { development }\end{array}$ & $\begin{array}{l}\text { Participation in the financing of new master's degree programs } \\
\text { at the Mohammed I University of Oujda; and support for the } \\
\text { scientific publication of researchers in the region. }\end{array}$ \\
\hline Promotion of local heritage & $\begin{array}{ll}- & \text { Encouragement of rural tourism and solidarity tourism } \\
- & \text { Development of knowledge related to the craft industry } \\
- & \text { Promotion of local products of the Oriental region }\end{array}$ \\
\hline Investment promotion & 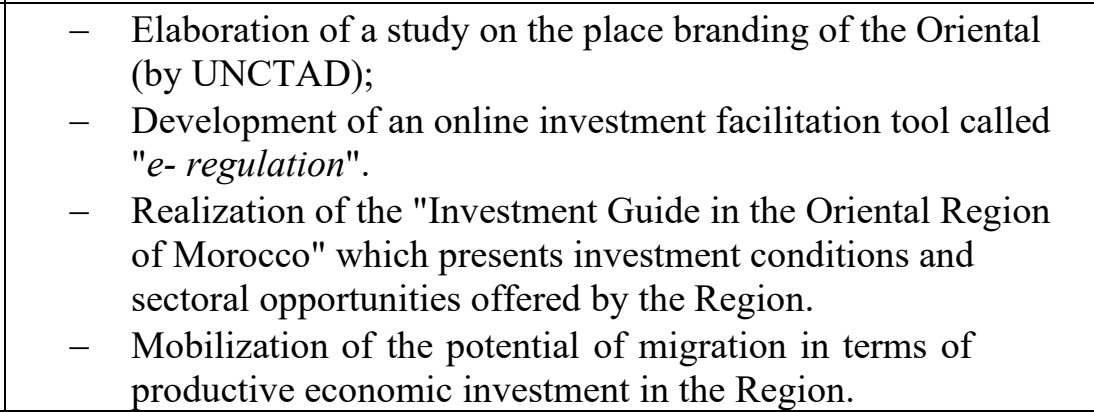 \\
\hline $\begin{array}{l}\text { Publication and production of } \\
\text { promotional documents for the } \\
\text { Region }\end{array}$ & $\begin{array}{l}\text { - Edition of the quarterly journal oriental.ma, which deals with } \\
\text { topics related to points of interest in the region. Published in } \\
2000 \text { copies, from the perspective of scientific, economic or } \\
\text { diplomatic analysis, this journal is intended for a specific } \\
\text { target of experts, intellectuals, and institutions. } \\
-\quad \text { Edition and free distribution of maps of the major cities of the } \\
\text { Region, intended to support the promotion of local tourism. } \\
-\quad \text { Edition of beautiful books and specialized guides (hiking } \\
\text { guide, gastronomic guide). }\end{array}$ \\
\hline \multirow[t]{2}{*}{ Objectives to be achieved } & Place Branding Tools Used \\
\hline & $\begin{array}{l}\text { Production and installation of numerous road signs along the } \\
\text { roads of the Oriental, intended to communicate the positive } \\
\text { changes that the Region has experienced. }\end{array}$ \\
\hline $\begin{array}{l}\text { Upgrading of the main cities in } \\
\text { the region }\end{array}$ & $\begin{array}{l}\text { - Participation in the requalification program of the main cities } \\
\text { of the Oriental region. }\end{array}$ \\
\hline $\begin{array}{l}\text { Internal place branding targeting } \\
\text { the local population }\end{array}$ & $\begin{array}{l}\text { Organization of a proximity caravan, where the Agency's } \\
\text { teams traveled through the various localities of the Region, in } \\
\text { urban and rural areas, to present the various public services } \\
\text { dedicated to economic and social development. }\end{array}$ \\
\hline $\begin{array}{l}\text { Digital marketing of the oriental } \\
\text { region through the web. }\end{array}$ & $\begin{array}{l}\text { - Launch of a portal with } 16 \text { sites, dedicated to the promotion of } \\
\text { various aspects of the region: tourism, culture, practical life, ... }\end{array}$ \\
\hline
\end{tabular}

\section{DISCUSSION AND CONCLUSIONS}

An analysis of the experiences of these three regions, the two French regions and the Moroccan region, shows that marketing practices in these different territories have many points in common, but nevertheless have many differences, which can be summarized below:

\section{Territorial Diagnosis}

The three territories went through a territorial diagnosis, before defining a regional marketing strategy. If in the French case, the diagnosis was participatory and the strategy was concerted and shared by the 
different actors of the territory, in the Moroccan case, the diagnosis was conducted on the territory, without the involvement of all the actors concerned, and the marketing strategy developed and implemented, by the Oriental Development Agency, without real involvement of all other actors.

\section{Vision and Strategy}

The marketing strategy of the Oriental region suffers from a major handicap. For the different actors interviewed, this approach lacks a clear vision of development and cannot be qualified as strategic. Indeed, the positioning of the Oriental remains to be found and validated by the actors of the territory (between the seaside resort, industry, agro-industry, renewable energies, etc.). In the same way, development strategies must promote creativity and innovation, and get out of the classical development models which have shown their limits.

\section{Financial Resources}

An integrated marketing approach requires a significant investment. It is true that creativity and ideas are needed, but sufficient funding must be available to hire competent human resources and produce the necessary work tools. In the case of the Oriental, many stakeholders in the territory, all categories taken together, think that the lack of financial resources granted by the public budget for place branding and communication are the cause of the failure of these approaches. Marketing has its own tools, which are budget-consuming. Supporting investors, organizing events, conducting a publishing policy, developing digital communication strategies, as well as the use of traditional media, radio and TV, newspapers and magazines, require significant funds that the Oriental region does not currently have.

\section{Investment Promotion}

The place branding strategy of the Oriental, one of the main pillars of which is the attraction and support of investors, is led by an actor, whose missions do not cover the field of investment. To overcome this constraint, it would have been necessary to work closely with the CRI of the Region. However, this coordination has not always taken place, and collaboration has been punctual and limited in time due to numerous conflicts between the main actors in the territory (Moussalim, 2017).

\section{Involvement of Key Players in the Region}

\section{Diaspora}

For both French regions, the development of a network of ambassadors, made up of members of the diaspora, is an important pillar of place branding strategies. In the Moroccan case, it has been found that an important player in this case is represented by the diaspora of the East, or Orientals of the world. The region does not necessarily count on them, wrongly, as ambassadors to speak and make speak about the region, but rather to come and invest in the various development projects launched in the region, while these two missions can be complementary. Thus, from time to time, the region organizes visits in the countries of destination of the emigration of the Oriental (Germany, Belgium, France) to meet them and present them the investment opportunities. There are also many projects developed by international cooperation (including the MIDEO project of the GIZ, an EU project) to approach the Eastern diaspora in these countries, present them with opportunities for productive investment in the region and help facilitate the related procedures.

\section{Universities}

Universities are important players in the marketing of cities and regions. In a world where fierce competition is played out on a global scale between the best universities, the question of the impact and repercussions of the existence of a large-scale academic institution on the territory that constitutes its more or less close environment remains little studied to this day. At the end of 2016, the Strasbourg Urban Development and Planning Agency (ADEUS) carried out an analysis of the catalytic effects of the University of Strasbourg, to try to better understand this opportunity. The results are edifying and provide guidance for public policies to develop the economic impact of universities on a territory. Thus, the presence 
of a university produces direct economic effects on the territory, which are of three different kinds: an image effect, an attractiveness effect, and an ecosystem effect. In the Oriental region, the Mohamed I University of Oujda will thus have a role to play in the marketing of the region, provided that public actors take the measure of the importance of this actor and put it better through public policies to encourage research \& development and the development of innovative education sectors.

\section{The Local Population, or Residents}

In the Oriental region, there is almost unanimity on the importance of involving the residents of the territory in the place branding approaches, even if the modalities of this involvement are not completely clear for the actors of the region. The current residents of the territory play an important role in shaping the image of the territory, especially in the current era of social networks. They can build a positive image oftheir territory when they talk about it positively, just as they can ruin all the efforts made by the actors, through their everyday behaviors (cabs, hotels, stores, waiters, etc.), as in the comments that currently accompany all the websites. Special attention must therefore be paid to this category, through public communication that will serve to rebuild trust between citizens and their elected officials, and by involving it in the reflection and implementation of marketing approaches carried out by the territory. Residents can play the role of ambassadors for the territory, both nationally and internationally.

\section{Concertation and Coordination Between the PPs of the Territory}

The actors of the marketing of the Oriental territories are very numerous and diversified: the State through its public institutions, the local authorities with the region at their head, the national institutional actors, the international cooperation, the associative sector, the private sector and its organizations, or the university, the residents of the territory and the orientals of the world. To date, there is little collaboration and cooperation around the marketing strategy of eastern territories, quite the opposite of what is happening on the other side of the Mediterranean. Without cooperation and coordination of efforts of all, there will be a waste of means and energies, and lack of effectiveness and efficiency of place branding projects, which may even lead to their failure.

\section{Branding $^{18}$}

As we have seen in the previous paragraphs, the two French regions launched territorial brands from the very beginning of their marketing strategies, as did the city of Casablanca, moreover, with the launch of its WeCasablanca brand. The Oriental Region also seems to lead this reflection. A seminar was organized in May 2016 by the Regional Council, in partnership with the Wilaya of the region and the agency of the Oriental, under the theme "New Regions, on your marks! For a reflection on the need for a territorial brand and the process to build it". This reflection has not been followed up to date. Some authors think that a territorial brand is indispensable and can be the first phase of any marketing approach for a territory. Others, and we are of the same opinion, think rather that giving a brand to a territory is not the first urgency in the framework of a place branding strategy, especially for territories that are experiencing development problems. Priority should be given first to improving the living conditions of the population, and for this the brand is not necessary.

\section{Research Contributions and Managerial Implications}

Place branding is a young discipline, in full evolution, too little taught at the university and the Grandes Ecoles, while the practice is very popular in developed countries, and still too little in Morocco. It is within this framework that our study has made it possible to analyze the perception of territorial actors of what place branding is, and to identify its stakeholders, within the framework of a Moroccan region.

Place branding is specific to each territory, and is built on its own characteristics. A marketing strategy cannot be duplicated for another territory, even if the tools may be globally the same. Our goal is not to generalize our findings to other Moroccan regions, or international. But rather to draw lessons that can be useful to them and avoid "mistakes" that can hinder the successful implementation of a marketing strategy. The managerial contributions for the actors of the Oriental Region, and for the actors of the other Moroccan 
regions, the context being generally the same, are numerous and are in relation with the importance of the territorial diagnosis, the vision and the strategy, and the implication of all the actors, public, private and associative, at the local, regional, national and international level. Benchmarking with French regions has shown that the management of this ambitious territorial project is generally entrusted to private structures, under the guidance of public- private networks. At the level of Morocco, this model cannot be applied immediately for several reasons. Communication agencies, whether national or regional, are not competent in place branding on the one hand, and this model of governance is not accepted, to date, by public actors, who retain control over development and place branding strategies.

\section{CONCLUSION}

The comparison of place branding practices between the French regions studied and the Moroccan Oriental region showed many similarities. However, there are marked differences in practices, which, without really constituting a specific model of the Moroccan region, represent marked particularities that can be found in other southern countries. Our study was able to show that without a vision, which is shared by all the actors, nor a development and marketing strategy, based on a participative diagnosis, the marketing of the region will be limited to punctual actions of promotion without real sustainable impact on regional marketing. In the same way, the promotion of investments and the upstream and downstream accompaniment of investors remains a key axis of any place branding strategy, which requires as much as the other components of the marketing strategy, a consequent budget, essentially public, but from which the private and associative sector will be able to benefit, for an integrated action in this field. As far as the actors concerned by the marketing of the Region are concerned, our study has shown the importance of mobilizing the diaspora of the region, strongly established in Europe, not only to send currency, which only transits through the region, but to play the role of ambassadors of the region. It is also important to mobilize the university established in the region, whose activities remain disconnected from its territory of implantation and do not involve other actors. And finally, the residents of the region should be better informed and also targeted by marketing actions, being themselves, at the same time, actors and targets of place branding of their region.

Nevertheless, more detailed studies, in more Moroccan regions, and other regions of the countries of the southern shore of the Mediterranean, are necessary to be able to draw the true contours of a place branding practice specific to these countries.

\section{ACKNOWLEDGEMENT}

Translated \& edited by American Publishing Services (https://americanpublishingservices.com/).

\section{ENDNOTES}

1. This is a competitive advantage, referred to in marketing as a "Unique Selling Proposal or Unique Selling Point" (Kotler et al. 1999, p. 31).

2. Within the framework of this research, we mobilized an important documentation composed of economic studies of the Oriental region, communal development plans (PCD), activity reports of the Agence de l'Oriental, the regional development strategy (elaborated by the Agence de l'Oriental), the regional development strategy (elaborated by the Regional Council), internal documents produced within the framework of the projects carried out by the Agence de l'Oriental, articles of specialized press, specialized reviews, texts of laws, ...

3. We conducted 27 semi-structured interviews with 28 managers at the national, regional and local levels.

4. N'Vivo is a software program that supports qualitative and combined research methods. It allows you to organize, analyze, and find insightful content from unstructured or qualitative data such as interviews, openended survey responses, articles, social media, and web pages.

5. OECD Territorial Reviews: Champagne-Ardenne, France. 2006. OECD Publishing. 272p. 
6. Celebrity Marketing is the use of stars and celebrities by various companies to be spokespersons for the brand or product.

7. Co-branding is a marketing or commercial practice that aims to simultaneously promote the brands or products of 2 distinct companies. The meeting of the 2 brands can be done in the form of a creation of a cobranded product mixing 2 originally distinct products or an advertisement associating 2 brands.

8. The "ch'ti" or "ch'timi" is the patois of Northern France, so called in Nord-Pas-de-Calais. It has been brought to the forefront thanks to the film by French comedian Dany Boon "Bienvenue chez les Ch'tis" (Welcome to the Ch'tis). This film was released in theaters in 2008 and was a huge success with the public. With more than 20 million admissions, it achieved the second best score at the French box office, slightly behind Titanic (20,758,887 admissions).

9. General Population and Housing Census 2014. Oujda Regional Directorate, April 2015. www.hcp.ma/regionoriental

10. HCP Oriental Regional Directorate (2016). Monograph of the Oriental region. 95

11. Activity report of the Agence de l'Oriental for the year 2005 and action plan 2006-2008.

12. The Agency supports many initiatives of local, regional, and even international actors, relating to festivals or sports activities organized in the Oriental region as well as in the rest of Morocco or internationally. It has also financed the production of a television program on the national channel intended for the Moroccan diaspora in the East.

13. The Agency financed the publication by UNCTAD of a study on the marketing of the Region and a guide on investment in the Oriental region, the only one produced on a region to date, in French, English and even Chinese.

14. Such as the oriental.ma magazine, beautiful books, tourist guides, maps of the region, as well as the scientific production by the researchers of the Region.

15. As an example, the proximity caravan, theater festivals, cinema, events around reading, ...

16. It is a portal of 16 sites based on 2.0 technology, including institutional sites, others dedicated to tourism or culture, or simply of a practical nature.

17. A detailed study of the marketing strategy of territories implemented by the agency of the Oriental was conducted by the author, in 2011, as part of a master's degree in public management at ISCAE Rabat, under the title "Place branding as a tool to strengthen the competitiveness and attractiveness of territories - Case of the Oriental region".

18. Branding is generally translated into French as "mise en marque" and therefore the expression "place branding" is translated into French as "mise en marque des territoires".

\section{REFERENCES}

Anholt, S. (2007). Competitive Identity. The new brand management for nations. Cities and Regions, p.134.

Ashworth, G.J., \& Voogd, H. (1994). Marketing and Place Promotion. In C. Wiley, J.R. Gold, \& S.V. Ward (Eds.), Place Promotion: The Use of Publicity and Marketing to Sell Towns and Regions (p.268).

Ben Hachem El Harouni, S. (2008). La construction régionale au Maroc: Dynamique et enjeux. REMALD, 60(Themes actuels), 488.

Benko, G. (1999). Cities and communication strategies and urban marketing. Pouvoirs Locaux - La Documentation Française, Paris, 42, 12-18.

Bennett, R., \& Savani, S. (2003). The rebranding of city places: An international comparative investigation. International Public Management Review, 4(2), 70-87.

Berglund, E., \& Olsson, K. (2010). Rethinking place marketing - A literature review. In 50th ERSA Congress Jönköping, $19^{\text {th }}-23 r d$ (pp. 1-19). Sweden.

Berry, L.L., \& Parasuraman, P.A. (1993). Building a new academic field - The case of services marketing. Journal of Retailing, 69(1), 13-60.

Braun, E. (2008). City Marketing: Towards an integrated approach. Erasmus University Rotterdam, Rotterdam.

Camagni, R. (2002). On the Concept of Territorial Competitiveness: Sound or Misleading? Urban Studies, 39(13), 2395-2411. 
Chamard, V., Liquet, J-C., \& Mengi, M. (2013). L'image de marque des régions françaises: Evaluation du -capital territoirell by the general public. Revue Française du Marketing, (244/245), 27-43.

Clark, G. (2002). Emerging Local Economic Development Lessons from Cities in the Developed World, and their applicability to Cities in Developing and Transitioning Countries.

Eshuis, J., Braun, E., \& Klijn, E. (2013). Place Marketing as governance strategy: An assessment of obstacles in place marketing and their effects on attracting target groups. Public Administration Review, 73(3), 507-516.

Greenberg, M. (2008). Branding New York: How a City in Crisis Was Sold to the World. New York: Routledge.

Hazelnut, P., \& Vallerugo, F. (2010). A world of cities: The marketing of sustainable territories. Ed. de l'Aube.

Hernandez, S. (2007). Le management territorial: le Renouvellement des modes d'intervention publics. In 16th International Colloquium of the Journal Politiques et Management Public (p.26). Public: News figures? News frontières?

Kavaratzis, M. (2004). From city marketing to city branding: Towards a theoretical framework for developing. Place Branding, 1(1), 58-73.

Kavaratzis, M. (2009). What can we learn from city marketing practice? European Spatial Research and Policy, 16(1), 41-58.

Kotler, P. (2009). Foreword. In T. Moilanen \& S. Rainisto, How to brand nations, cities and destinations. A planning book for place branding (p.202). New York.

Kotler, P., \& Gertner, D. (2002). Country as brand, product and beyond: A place marketing and brand management perspective. The Journal of Brand Management, 9(4), 249-261.

Kotler, P., Asplund, C., Rein, I., \& Heider, D. (1999). Marketing Places Europe: Attracting Investments, Industries, Residents and Visitors to European Cities, Communities, Regions and Nations. Harlow: Financial Times/Prentice-Hall.

Langeard, E., \& Eiglier, P. (1987). Servuction. Mc Graw-Hill.

Meyronin, B. (2009). Marketing territorial. Vuibert, Paris.

Moussalim, S. (2017). The organizational capacity of a territory as a lever of its territorial development. (PhD thesis). ISCAE Casablanca, p.383.

Proulx, M., \& Tremblay, D. (2006). Territorial marketing and global positioning. Géographie, Economie, Société, 8(2), 239-256.

Rainisto, S.K. (2003). Success factors of place marketing: A study of place marketing practices in Northern Europe and the United States. Helsinki University of Technology.

Rocket, C., \& Cassiere, F. (2012, January 19-21). The brand Région: Between the technical acculturation of local authorities and regional identity. In 11th International Marketing Trends Conference (p.4). Venice.

Shostack, L.G. (1977). Breaking free from product marketing. Journal of Marketing, 41(2), 73-80.

Van Den Berg, L., \& Braun, E. (1999). Urban Competitiveness, Marketing and the Need for Organising Capacity. Urban Studies, 36(5-6), 987-999.

Vuignier, R. (2016). Territorial marketing and branding territorial: A systematic literature review. Lausanne.

Ward, S. (1998). Selling Places: The Marketing and Promotion of Towns and Cities 1850-2000. Londres: Routledge, Oxon. P.

Yin, R.K. (2003). Applications of Case Study Research (Applied Social Research Methods). Sage Publications, Inc. 


\section{APPENDIX}

\section{PANEL OF ACTORS INTERVIEWED}

\begin{tabular}{|c|c|}
\hline Structure & Representative \\
\hline Wilaya of the Oriental & $\begin{array}{l}\text { Mr. Mohamed Mhidia, Wali of the Oriental region and } \\
\text { Governor of Oujda Angad Prefecture }\end{array}$ \\
\hline Oriental Regional Council & $\begin{array}{l}\text { Mr. Ali Belhaj, President of the Oriental region (at the time of } \\
\text { the study) }\end{array}$ \\
\hline Oriental Regional Council & Mr. Mohamed Mrabet, 1st Vice-President \\
\hline Oriental Regional Council & Me Masbahi, $3^{\text {rd }}$ Vice-President of the Region \\
\hline Oriental Regional Council & $\begin{array}{l}\text { Mrs. Fatima-Zahra Zahraoui, Project Officer, Head of the } \\
\text { President's Office }\end{array}$ \\
\hline Jerada Provincial Council & Mr. Mohamed Abdellaoui, President \\
\hline Municipal Council of Figuig & $\begin{array}{l}\text { Mr. Amar Abbou, Former Mayor of Figuig, former Vice } \\
\text { President of the region and current Regional Director of Culture }\end{array}$ \\
\hline Oriental Agency & Mr. Mohamed Mbarki, General Manager \\
\hline Oriental Agency & Mr. Taoufiq Boudchiche, Director of International Cooperation \\
\hline Oriental Agency & Ms. Karima El Ghayam, Policy Officer in the Office of the CEO \\
\hline $\begin{array}{l}\text { Investment Fund of the Oriental } \\
\text { (FIRO) }\end{array}$ & $\begin{array}{l}\text { Mr. Abdelkrim Mahdi, Director General and CGEM } \\
\text { representative for the Oriental region }\end{array}$ \\
\hline Regional Investment Centre & Mr. Mohamed Sabri, Director \\
\hline Ministry of Tourism & $\begin{array}{l}\text { Mr. Allal Bouguerne, Director of Operations at the Moroccan } \\
\text { Tourism Engineering Company (SMIT) }\end{array}$ \\
\hline Regional Tourism Delegation & Mr. Mohamed Abdellaoui, Director \\
\hline $\begin{array}{l}\text { Regional Direction of Agriculture of } \\
\text { the Oriental region }\end{array}$ & Mr. Mohamed Bakkaoui, Director \\
\hline $\begin{array}{l}\text { Regional Direction of Agriculture of } \\
\text { the Oriental region }\end{array}$ & Mr. Mohamed Benhafoune, Head of Statistics Department \\
\hline $\begin{array}{l}\text { Moroccan Agency for Investment } \\
\text { Development (AMDI) }\end{array}$ & $\begin{array}{l}\text { Mrs. Safae Sijilmassi, Director of the International Relations } \\
\text { Department }\end{array}$ \\
\hline AMDI & $\begin{array}{l}\text { Mrs. Jihane Lmimouni, Head of International Organizations } \\
\text { Department }\end{array}$ \\
\hline MEDZ Oriental & Mr. Rachid Rami, Director \\
\hline $\begin{array}{l}\text { Company 1: Design and architecture } \\
\text { office }\end{array}$ & Mr. Jamal Boudchiche, Director \\
\hline Company 2: ANOCTIS & Ms. Isabelle Pfenninger, Director \\
\hline Association ZOUZFANA (Figuig) & Mr. Badiss Tayeb, President \\
\hline $\begin{array}{l}\text { Oriental Morocco Association for } \\
\text { Sustainable Development }\end{array}$ & Mr. Abderahmane Mejdoubi, President \\
\hline Association ASTICUDE & Mr. Abdeslam Amakhtari, President \\
\hline Mohamed I University & Mrs. Ouaffa Brahim, Teacher-researcher, COM Manager \\
\hline Multilateral cooperation & Mr. Julien Bornon, UNCTAD Expert in Morocco \\
\hline Bilateral cooperation & Mr. Pascal Bracquemond, Director IF Oujda \\
\hline Journal L'Economiste & Mr. Mohamed Benabid, Editor-in-Chief \\
\hline Communication agency TOPIC & Mr. Philippe Michel, Director \\
\hline
\end{tabular}

